\title{
ROADWAY DESIGN EFFICIENCY INDICES FOR HARD COAL MINES
}

\author{
Piotr MAŁKOWSKI *, Zbigniew NIEDBALSKI and Tadeusz MAJCHERCZYK
}

\section{ARTICLE INFO}

Article history:

Received 10 October 2015

Accepted 22 January 2016

Available online 12 February 2016

Keywords:

Underground roadways stability

Roadway Design Efficiency index

Roadway Functionality Maintenance index

\begin{abstract}
Maintaining roadway stability is one of the crucial problems in the process of designing mining operations. There are many geotechnical systems and ratings describing the geological nature of rock mass, but only a few which take into account the mining and technical factors. The authors have therefore developed two practical indices for a quick and easy roadway stability assessment: Roadway Design Efficiency index ("RDE"); and Roadway Functionality Maintenance index ("RFM"). RDE can provide information regarding potential difficulties in ensuring roadway stability in advance of working drivage, based on geological, geomechanical and mining data. RFM evaluates the success of roadway maintenance in a given time range for the selected technical solutions. These indices can also help in choosing the design method for reinforcement of the underground support. Low values suggest the necessity of increasing support load bearing capacity. The rank of the geological, mining and technical factors is based on Analytic Hierarchy Process analysis and the data come from the survey carried out among mining engineers. The calculated RDE and RFM indices have been compared to the results of in situ measurements in the selected underground hard coal workings.
\end{abstract}

\section{INTRODUCTION}

Underground roadway design is complex, as it takes into account many different geological, mining and technical factors and relies on experience.

The methodology of designing the underground construction based on a flowchart was included, among others, in the Feng and Hudson (2011). It was shown that the method could equally relate to mining roadways. The scheme proposed in Feng and Hudson (2011) covers the direct design process of underground construction. The process is divided into seven stages, starting from the project purpose, key features of the site, then strategy, choice of modelling method, initial design, feedback information, and final design. Every stage of design establishes the essential tasks to be completed.

There is a slightly different approach in Canbulat (2010), who describes a process of designing the support in hard coal mines. While it is necessary to have an understanding of the mining and geological conditions applied in each case, the financial benefits related to possible support types are not analysed in early stages. Likewise, potential hazards from underground construction instability are not considered in the initial design.

During the design process there are some cases where the specific mining and geological conditions and roadway support schemes would be inappropriate, especially roadways at the great depths or in geologically disturbed regions. Currently, however, some mining roadways are driven at a depth of $1200 \mathrm{~m}$ or deeper and their frequency is expected to increase in the coming years. It therefore appears that there is a need to develop a design method which would maintain underground roadway stability, regardless of conditions.

Mishra and Rinne (2014) developed the geotechnical risk assessment ("GRA") method for underground workings, based both on qualitative parameters (available geotechnical data) and on quantitative parameters (such as mining design planning or support calculation). To assess the likelihood and consequences of mining working instability, Mishra and Rinne divided the evaluation process into three stages: identification of the hazards for a given site, selection of risk assessment parameters, and risk analysis. Using hazard identification tools and risk assessment parameters (with certain weight), they were able to assess if a risk exists, could be mitigated, or completely avoided.

In the case of soft rocks prone to separate, one of the most important stages of mining should be the proper design of supports to suit to the changing mining and geological situation. The situation can 
Table 1 Factors affecting the roadways design and their maintenance derived by AHP.

\begin{tabular}{|c|c|c|c|c|}
\hline \multicolumn{5}{|c|}{ Factor and its weight [\%] } \\
\hline No. & Geological & Geomechanical & Mining & Technical \\
\hline 1 & $\begin{array}{l}\text { Distance between fault } \\
\text { and roadway }-20.6\end{array}$ & $\begin{array}{c}\text { Rock quality designation } \\
\text { RQD }-21.7 \\
\end{array}$ & $\begin{array}{c}\text { Exploitation workings } \\
\text { nearby }-24.3 \\
\end{array}$ & $\begin{array}{c}\text { Load capacity of the support } \\
\text { system }-24.7\end{array}$ \\
\hline 2 & Seismic activity -17.4 & $\begin{array}{l}\text { UCS weighted avarage for } \\
\text { the roof }-20.9\end{array}$ & $\begin{array}{c}\text { Exploitation edge } \\
\text { influence }-23.5 \\
\end{array}$ & $\begin{array}{l}\text { Precision of support } \\
\text { workmanship }-14.3 \\
\end{array}$ \\
\hline 3 & $\begin{array}{c}\text { Geomechanical } \\
\text { parameters }-17.2 \\
\end{array}$ & $\begin{array}{l}\text { Brasilian tensile strength of } \\
\text { the roof }-15.3\end{array}$ & $\begin{array}{l}\text { Pillars and unmined } \\
\text { areas nearby }-20.8\end{array}$ & Type of support - 13.6 \\
\hline 4 & $\begin{array}{l}\text { Drivage along the fault } \\
\text { zone }-16.9\end{array}$ & $\begin{array}{l}\text { UCS weighted avarage for } \\
\text { the wall }-13.6\end{array}$ & The goafs -18.1 & $\begin{array}{c}\text { Time range of roadway } \\
\text { maintenance }-13.6\end{array}$ \\
\hline 5 & $\begin{array}{l}\text { The thin beds in the } \\
\text { immediate roof }-9.3\end{array}$ & $\begin{array}{c}\text { Slakeability of the roof } \\
\text { rock }-13.3\end{array}$ & The depth -7.8 & $\begin{array}{l}\text { The roadway's size and shape - } \\
12.8\end{array}$ \\
\hline 6 & $\begin{array}{c}\text { Hydrogeological } \\
\text { conditions }-8.0\end{array}$ & $\begin{array}{l}\text { UCS weighted avarage for } \\
\text { the floor }-8.3\end{array}$ & $\begin{array}{c}\text { Other roadways } \\
\text { nearby }-5.4\end{array}$ & Type of lagging -9.3 \\
\hline 7 & Drivage in the fold -6.1 & $\begin{array}{l}\text { Unit weight of the } \\
\text { immediate roof }-7.1\end{array}$ & & Drivage with blasting -5.1 \\
\hline 8 & Rock beds gradient -4.5 & & & Speed of roadway drivage -3.2 \\
\hline 9 & & & & Drivage with shearer -3.1 \\
\hline
\end{tabular}

then be monitored by the geotechnical measurements in the rock mass (such as Wang and Fan, 2000).

In the terms of Polish coal mines, steel yielding supports are the main protection against rock movements, with one scheme of support usually developed for the whole mine, assuming the modified support scheme in the initial design can be optimised; that is, proper support for the working with changing mining and geological conditions (Małkowski et al., 2012).

Based on the existing methods of design as well as the authors' own research, this paper proposes a new method of hard coal mine roadways stability assessment. Based on geological, mining and technological data, two indices have been developed: Roadway Design Efficiency index ("RDE"), which indicates the extent of problems that can be associated with roadway designing; and Roadway Maintenance Functionality index ("RFM"), which indicates the difficulties that may occur during roadway use. Both indices are based on rating points and weightings for the factors obtained from the Analytic Hierarchy Process (“AHP”) method of analysis. Some examples of method application with the in situ measurements results in the field have also been presented.

\section{USING AHP METHOD FOR ROADWAYS DESIGNING}

One of the most important aspects of underground construction design, including roadway support, is recognition of the physical properties of the rock mass while taking into consideration mining factors and geological conditions. The problems considered can be assumed as multi-criterial, because of the large number of varied factors, partly described qualitatively (rockburst energy, depth, rock quality designation $R Q D$, for example) and partly described quantitatively (type of support, hydrogeological conditions, workmanship, etc). One method to solve this problem is AHP, which allows for the selection of factors and ranks their importance.

The AHP method has long been used as a tool for supporting a decision-making process in problematic and unequivocal situations (Saaty, 1980), although the method was also applied to more typical mining problems (Jamshidi et al., 2009; Namin et al., 2009; Guptaa and Kumarb, 2012). Surveys using AHP were also developed to determine the importance of natural, mining and technical factors for designing roadway supports and their maintenance (Małkowski et al., 2012). In total, 27 factors were considered, which were divided into three groups and two subgroups. By comparing each parameter to the next in the group, their importance in support design and roadway maintenance is considered to be: geological factors: $43.63 \%$, mining factors: $31.66 \%$, and technical factors: $24.71 \%$.

Pair wise comparison of the main groups of factors has shown that geological factors influence the effectiveness of roadway design in hard coal mines the most. It was also considered that technical factors are the least significant parameters in roadway maintenance.

The factors affecting the roadways design and maintenance derived by AHP and their rank are presented in Table 1.

The above results of the AHP analysis were used to develop indices for evaluating the effectiveness of roadway design and maintenance.

The identification of key factors which influence the roadway design process can also help in roadway stability maintenance evaluation for the specific time range. The research results presented have been examined closely with the relation to roadway stability and functionality. 
The roadway cycle can be divided into three stages: designing, development and exploitation. Each stage is influenced by specific factors and the appropriate effect of the next stage can be reached only if only the high quality works are carried out in the previous stage.

It is possible to distinguish two stages of the potential effective design and effective functioning of the roadway. In the first or design stage, geological and mining factors should be analysed, together with the method of developing the roadway. The analysis allows for the evaluation of potential difficulties in maintaining roadway stability and in the support design process. In the second stage, technical factor analysis should be carried out, especially of, which allows for roadway maintenance assessment for a specific time range.

\section{ROADWAY DESIGN EFFICIENCY INDEX AND ROADWAY FUNCTIONALITY MAINTENANCE INDEX}

In order to assess the level of support design efficiency, results of AHP research were used (Niedbalski, 2014). Based on the individual feature hierarchy, a point algorithm has been created. Each factor and its influence ratio on support design efficiency and roadway functionality is shown in Tables 3, 4, 5 and 7. The sum of the weight of the

Table 2 Description of slakeability and value of $r$ index.

\begin{tabular}{clc}
\hline No. & \multicolumn{1}{c}{ Description } & Index $r$ \\
\hline 1 & Water does not change a rock structure and cohesion & 1.0 \\
2 & The rock cracks parallel to the beds & 0.8 \\
3 & The rock crack parallel to the beds and perpendicular to them & 0.6 \\
4 & The rock cracks dense & 0.4 \\
5 & The rock structure changes into debris & 0.2 \\
6 & The rock changes into mud & 0.1 \\
\hline
\end{tabular}

Table 3 The range of geological factor variation $N_{N}$.

\begin{tabular}{|c|c|c|c|c|}
\hline No. & Factor & $\begin{array}{c}\text { The weight } \\
\text { of the factor } \\
w_{p}[\%]\end{array}$ & The factor description & $\begin{array}{c}\text { Influence } \\
\text { ratio } \\
w_{w} \\
\end{array}$ \\
\hline 1 & $\begin{array}{l}\text { The fault crossed } \\
\text { the roadway }\end{array}$ & 28.6 & $\begin{array}{l}\text { none } \\
\text { throw of fault up to } 2 \mathrm{~m} \\
\text { throw of fault up to } 5 \mathrm{~m} \\
\text { throw of fault up to } 10 \mathrm{~m} \\
\text { throw of fault above } 10 \mathrm{~m}\end{array}$ & $\begin{array}{l}1 \\
0.8 \\
0.6 \\
0.4 \\
0.2 \\
\end{array}$ \\
\hline 2 & Seismic activity & 24.1 & $\begin{array}{l}\text { none } \\
\text { rockbursts with energy up to } 10 \mathrm{E} 3 \mathrm{~J} \\
\text { rockbursts with energy up to } 10 \mathrm{E} 4 \mathrm{~J} \\
\text { rockbursts with energy up to } 10 \mathrm{E} 5 \mathrm{~J} \\
\text { rockbursts with energy over } 10 \mathrm{E} 5 \mathrm{~J}\end{array}$ & $\begin{array}{l}1 \\
0.8 \\
0.6 \\
0.4 \\
0,2\end{array}$ \\
\hline 3 & $\begin{array}{c}\text { Drivage along the fault } \\
\text { zone }\end{array}$ & 23.4 & $\begin{array}{l}\text { none } \\
\text { throw of fault up to } 10 \mathrm{~m} \\
\text { throw of fault up to } 20 \mathrm{~m} \\
\text { throw of fault up to } 50 \mathrm{~m} \\
\text { drivage in the fault zone }\end{array}$ & $\begin{array}{l}1 \\
0.8 \\
0.6 \\
0.4 \\
0.2 \\
\end{array}$ \\
\hline 4 & $\begin{array}{l}\text { The thin beds lying in } \\
\text { the immediate roof } \\
(6-8 \mathrm{~m})\end{array}$ & 12.9 & $\begin{array}{l}\text { beds with the thickness of over } 3 \mathrm{~m} \\
\text { beds with the thickness of over } 2 \mathrm{~m} \\
\text { beds with the thickness of over } 0.5 \mathrm{~m} \\
\text { beds with the thickness of over } 0.2 \mathrm{~m} \\
\text { beds with the thickness of under } 0.2 \mathrm{~m} \\
\end{array}$ & $\begin{array}{l}1 \\
0.8 \\
0.6 \\
0.4 \\
0.2\end{array}$ \\
\hline 5 & $\begin{array}{l}\text { Hydrogeological } \\
\text { conditions }\end{array}$ & 11.0 & $\begin{array}{c}\text { no water levels - impermeable rocks in a roof } \\
\text { no water levels - permeable rocks in a roof } \\
\text { water level above the roof - impermeable rocks in } \\
\text { a roof with the thickness of over } 8 \mathrm{~m} \\
\text { water level above the roof - impermeable rocks in } \\
\text { a roof with the thickness of less than } 8 \mathrm{~m} \\
\text { water level above the roof - permeable roof rocks }\end{array}$ & $\begin{array}{l}1 \\
0.8 \\
0.6 \\
0.4 \\
0.2\end{array}$ \\
\hline
\end{tabular}


Table 4 The range of geomechanical factor variation $N_{G m}$.

\begin{tabular}{|c|c|c|c|c|}
\hline No. & Factor & $\begin{array}{c}\text { The weight of } \\
\text { the factor } \\
w_{p}[\%]\end{array}$ & The factor description & $\begin{array}{c}\text { Influence } \\
\text { ratio } \\
w_{w} \\
\end{array}$ \\
\hline 1 & $\begin{array}{c}\text { Rock quality designation } \\
\text { RQD }\end{array}$ & 25.6 & $\begin{array}{c}\text { over } 90 \% \\
\text { over } 75 \% \\
\text { over } 50 \% \\
\text { over } 25 \% \\
\text { below } 25 \% \\
\end{array}$ & $\begin{array}{l}1 \\
0.8 \\
0.6 \\
0.4 \\
0.2\end{array}$ \\
\hline 2 & $\begin{array}{l}\text { UCS of the roof } \\
\sigma_{\mathrm{cr}}\end{array}$ & 24.5 & $\begin{array}{c}\text { over } 80 \mathrm{MPa} \\
\text { over } 60 \mathrm{MPa} \\
\text { over } 40 \mathrm{MPa} \\
\text { over } 20 \mathrm{MPa} \\
\text { up to } 20 \mathrm{MPa}\end{array}$ & $\begin{array}{l}1 \\
0.8 \\
0.6 \\
0.4 \\
0.2\end{array}$ \\
\hline 3 & $\begin{array}{c}\text { Brazilian tensile strength } \\
\text { of the roof } \\
\sigma_{\mathrm{tr}}\end{array}$ & 18.1 & $\begin{array}{c}\text { over } 8 \mathrm{MPa} \\
\text { over } 6 \mathrm{MPa} \\
\text { over } 4 \mathrm{MPa} \\
\text { over } 2 \mathrm{MPa} \\
\text { up to } 2 \mathrm{MPa}\end{array}$ & $\begin{array}{l}1 \\
0.8 \\
0.6 \\
0.4 \\
0.2\end{array}$ \\
\hline 4 & $\begin{array}{l}\text { UCS of the side } \\
\qquad \sigma_{\mathrm{cs}}\end{array}$ & 16.1 & $\begin{array}{c}\text { over } 40 \mathrm{MPa} \\
\text { over } 30 \mathrm{MPa} \\
\text { over } 20 \mathrm{MPa} \\
\text { over } 10 \mathrm{MPa} \\
\text { up to } 10 \mathrm{MPa}\end{array}$ & $\begin{array}{l}1 \\
0.8 \\
0.6 \\
0.4 \\
0.2\end{array}$ \\
\hline 5 & $\begin{array}{c}\text { Slakeability } \\
\mathrm{r} \\
\text { (Kidybiński, 2004) }\end{array}$ & 15.7 & $\begin{array}{l}r=1 \\
r \geq 0.8 \\
r \geq 0.6 \\
r \geq 0.4 \\
r \geq 0.2\end{array}$ & $\begin{array}{l}1 \\
0.8 \\
0.6 \\
0.4 \\
0.2\end{array}$ \\
\hline
\end{tabular}

Table 5 The range of mining factor variation $N_{G r}$.

\begin{tabular}{|c|c|c|c|c|}
\hline No & Factor & $\begin{array}{c}\text { The weight of } \\
\text { the factor } \\
w_{p}[\%]\end{array}$ & The factor description & $\begin{array}{l}\text { Influence ratio } \\
\qquad w_{w}\end{array}$ \\
\hline 1 & $\begin{array}{l}\text { Exploitation workings } \\
\text { nearby }\end{array}$ & 28.0 & $\begin{array}{c}\text { none } \\
\text { yes, } \mathrm{h} \leq 2 \mathrm{~m} \text {, with a distance of over } 50 \mathrm{~m} \\
\text { yes, } \mathrm{h}>2 \mathrm{~m} \text {, with a distance of over } 50 \mathrm{~m} \\
\text { yes, } \mathrm{h} \leq 2 \mathrm{~m} \text {, with a distance of below } 50 \mathrm{~m} \\
\text { yes, } \mathrm{h}>2 \mathrm{~m} \text {, with a distance of below } 50 \mathrm{~m}\end{array}$ & $\begin{array}{l}1 \\
0.8 \\
0.6 \\
0.4 \\
0.2\end{array}$ \\
\hline 2 & $\begin{array}{l}\text { Exploitation edge } \\
\text { influence }\end{array}$ & 27.1 & $\begin{array}{l}\mathrm{D}>80 \mathrm{~m} \\
\mathrm{D}>60 \mathrm{~m} \\
\mathrm{D}>40 \mathrm{~m} \\
\mathrm{D} \geq 20 \mathrm{~m} \\
\mathrm{D}<20 \mathrm{~m}\end{array}$ & $\begin{array}{l}1 \\
0.8 \\
0.6 \\
0.4 \\
0.2\end{array}$ \\
\hline 3 & $\begin{array}{l}\text { Pillars and unmined } \\
\text { areas nearby }\end{array}$ & 24.1 & $\begin{array}{c}\text { none } \\
\text { shaft pillar or full-mined coal seam } \\
\text { barrier pillar, a width over } 50 \mathrm{~m} \\
\text { barrier pillar, a width over } 25 \mathrm{~m} \\
\text { barrier pillar, a width below } 25 \mathrm{~m}\end{array}$ & $\begin{array}{l}1 \\
0.8 \\
0.6 \\
0.4 \\
0.2\end{array}$ \\
\hline 4 & The goafs & 20.8 & $\begin{array}{l}\text { none } \\
\text { below the seam or above the seam } \\
\text { in the seam, distance } 50-100 \mathrm{~m} \\
\text { in the seam, distance } 20-50 \mathrm{~m} \\
\text { in the seam, distance below } 20 \mathrm{~m}\end{array}$ & $\begin{array}{l}1 \\
0.8 \\
0.6 \\
0.4 \\
0.2\end{array}$ \\
\hline
\end{tabular}

\footnotetext{
* the height of a longwall panel
} 
Table 6 The efficiency of designing a roadway support in the hard coal mines.

\begin{tabular}{clr}
\hline Class & \multicolumn{1}{c}{ Description } & $\begin{array}{r}\text { RDE index } \\
\text { [points] }\end{array}$ \\
\hline I & Very favourable mining and geological conditions for designing & $261-300$ \\
II & Favourable mining and geological conditions for designing & $221-260$ \\
III & Average mining and geological conditions for designing & $181-220$ \\
IV & Unfavourable mining and geological conditions for designing & $141-180$ \\
V & Very unfavourable mining and geological conditions for designing & $101-141$ \\
VI & Lack of possibilities to design a safe support & $60-100$ \\
\hline
\end{tabular}

factors was $100 \%$. Because of the important role of geomechanical rock properties in the design and maintenance process, it was assumed that these properties are equivalent to the mining and geological factors (Canbulat, 2010; Małkowski et al., 2012; Protosenya and Trushko, 2013). The range of any factor variation fits the five class from the highest, which have a positive influence the design process (the influence ratio equals 1.0), to the lowest, which makes the design process difficult (the influence ratio equals 0.2 ). The influence ratios have been adjusted to the factors on the basis of the authors' many years of experience in roadway support design in coal mines. All of the factors with the weight below $10 \%$ have been discounted in the evaluation system as inessential for a mining practice.

A range of factor variations has been developed by the authors, based on their experience in roadway support design for the hard coal mines. The slakeability index $r$ was developed by the Central Mining Institute in Poland. The slakeablity test requires that a sample of rock is immersed in water for 24 hours, dried for 24 hours, and again immersed into the water for 24 hours (Kidybiński, 2004). The Table 2 shows the slakeability index $r$ in relation to rock behaviour after a water treatment. Table 3 shows the range of geological factor variation $N_{N}$. It is worth noting that all chosen geological and mining factors can affect the change of a vertical or horizontal stress around the roadway. The geomechanical and mining factors, with their range of variation, are given in Tables 4 and 5 , respectively.

The factors shown in Tables 3-5 allow a new parameter, Roadway Design Efficiency index RDE to be proposed to describe the scale of difficulties in the proper support design for the specific mining and geological conditions (Niedbalski, 2014), which is calculated as:

$$
R D E=\sum\left(N_{N}, N_{G M}, N_{G}\right)
$$

where:

- $N_{N}$ the sum of points for geological factors, calculated from Table 3 , as:
$N_{N}=\sum_{i=1}^{i=7} w_{p i} \cdot w_{w i}$

- $N_{G M}$ the sum of points for geomechanical factors, calculated from Table 4, as:

$N_{G m}=\sum_{i=1}^{i=7} w_{p i} \cdot w_{w i}$

- $N_{G}$ the sum of points for mining factors, calculated from Table 5, as:

$N_{G}=\sum_{i=1}^{i=6} w_{p i} \cdot w_{w i}$

- $w_{p i}$ the weight of the specific factor, \% (from Tables 3 - 5); and

- $w_{w i}$ the influence ratio of the specific factor (from Tables 3 - 5).

Given the most favourable mining and geological conditions, where every factor gets the highest possible mark, the support design efficiency index RDE will be 300; similarly, applying the least favourable conditions results in the poorest marks, resulting in an RDE index of 60 . Six class ranks were developed (Table 6), where class VI means the lack of possibilities to design a safe support which immediately suggests the roadway needs to be relocated.

The second stage of the efficiency evaluation is the assessment of the roadway stability in the required time period for the chosen technical solutions. The most important is a support type selection and its parameters which mainly determines roadway stability (Table 7, factors Nos. 1, 3 and 6). It is worth pointing out that it can only be estimated, since it is only possible to assess the workmanship after driving is completed (Table 7, factor No. 2).

Based on data included in Table 7 and RDE index, Roadway Functionality Maintenance index RFM was developed. The RFM index is conditional on the RDE index, because the geological and mining conditions are also essential for maintaining roadway 
Table 7 The range of technical factor variation $N_{T}$.

\begin{tabular}{|c|c|c|c|c|}
\hline No. & Factor & $\begin{array}{c}\text { The weight } \\
\text { of the factor } \\
w_{p}[\%]\end{array}$ & The factor description & $\begin{array}{l}\text { Influence ratio } \\
\qquad w_{w}\end{array}$ \\
\hline \multirow{5}{*}{1} & \multirow{5}{*}{$\begin{array}{l}\text { Load capacity of the } \\
\text { support system }\end{array}$} & \multirow{5}{*}{27.9} & $\mathrm{~N}>400 \mathrm{kN} / \mathrm{m}$ & 1 \\
\hline & & & $\mathrm{N} \leq 400 \mathrm{kN} / \mathrm{m}$ & 0.8 \\
\hline & & & $\mathrm{N} \leq 300 \mathrm{kN} / \mathrm{m}$ & 0.6 \\
\hline & & & $\mathrm{N} \leq 200 \mathrm{kN} / \mathrm{m}$ & 0.4 \\
\hline & & & $\mathrm{N} \leq 100 \mathrm{kN} / \mathrm{m}$ & 0.2 \\
\hline \multirow{5}{*}{2} & \multirow{5}{*}{$\begin{array}{l}\text { Precision of support } \\
\text { workmanship }\end{array}$} & \multirow{5}{*}{16.1} & very good & 1 \\
\hline & & & good & 0.8 \\
\hline & & & average & 0.6 \\
\hline & & & poor & 0.4 \\
\hline & & & very poor & 0.2 \\
\hline \multirow{5}{*}{3} & \multirow{5}{*}{ Type of support } & \multirow{5}{*}{15.8} & $\begin{array}{l}\text { Steel yielding support with the additional } \\
\text { roof beams along the working bolted to the } \\
\text { roof }\end{array}$ & 1 \\
\hline & & & $\begin{array}{l}\text { Steel yielding support with bolting between } \\
\text { the arches }\end{array}$ & 0.8 \\
\hline & & & $\begin{array}{l}\text { Steel yielding support with a bolted roof-bar; } \\
\text { steel yielding support reinforced with beams } \\
\text { on props; rigid steel support }\end{array}$ & 0.6 \\
\hline & & & $\begin{array}{l}\text { Rockbolting; steel yielding support } \\
\text { reinforced with steel/wooden beams along } \\
\text { the working }\end{array}$ & 0.4 \\
\hline & & & Steel yielding support & 0.2 \\
\hline \multirow{5}{*}{4} & \multirow{5}{*}{$\begin{array}{l}\text { Time range of roadway } \\
\text { maintenance }\end{array}$} & \multirow{5}{*}{15.3} & up to 1 year & 1 \\
\hline & & & up to 2 years & 0.8 \\
\hline & & & up to 5 years & 0.6 \\
\hline & & & up to 10 years & 0.4 \\
\hline & & & longer than 10 years & 0.2 \\
\hline \multirow{5}{*}{5} & \multirow{5}{*}{ Roadway size and shape } & \multirow{5}{*}{14.4} & arched: width $<5 \mathrm{~m}$; height $<3.5 \mathrm{~m}$ & 1 \\
\hline & & & arched: width $\geq 5 \mathrm{~m}$; height $\geq 3.5 \mathrm{~m}$ & 0.8 \\
\hline & & & arched: width $\geq 7 \mathrm{~m} ;$ height $\geq 4.5 \mathrm{~m}$ & 0.6 \\
\hline & & & rectangular: width $<6 \mathrm{~m}$; height $<3 \mathrm{~m}$ & 0.4 \\
\hline & & & rectangular: width $\geq 6 \mathrm{~m}$; height $\geq 3 \mathrm{~m}$ & 0.2 \\
\hline \multirow{5}{*}{6} & \multirow{5}{*}{ Type of lagging } & \multirow{5}{*}{10.5} & $\begin{array}{c}\text { Steel heavy chain screen mesh }+ \text { grout } \\
\text { lagging system }\end{array}$ & 1 \\
\hline & & & Concrete blocks + loose rock lagging & 0.8 \\
\hline & & & $\begin{array}{c}\text { Steel heavy chain screen mesh }+ \text { loose rock } \\
\text { lagging }\end{array}$ & 0.6 \\
\hline & & & Steel chain screen mesh + loose rock lagging & 0.4 \\
\hline & & & Steel hook screen mesh + loose rock lagging & 0.2 \\
\hline
\end{tabular}

stability in the future. The formula to obtain the RFM index is as follows:

$$
R F M=N_{T} \frac{R D E}{R D E_{\max }}
$$

where:

$N_{T}$ the sum of points for technical factors, calculated from Table 7, as:

$$
N_{T}=\sum_{i=1}^{i=7} w_{p i} \cdot w_{w i}
$$

$R D E$ the running value of Roadway Design Efficiency index; and
$R D E_{\max }$ the maximum value of Roadway Design Efficiency index equal 300.

Using formula (5), the potential roadway stability maintenance classification was developed (Table 8). The RFM index ranges from 4 to 100 points with six classes of stability maintenance.

The proposed methodology allows the level of difficulties to be evaluated in keeping with roadways stability and functionality, not only for design workings, but also for existing roadways. Furthermore, there is a possibility to verify factors and their changes if the mining conditions have been altered or if new geological or geomechanical data 
Table 8 The classification of roadways stability maintenance effectiveness in the hard coal mines.

\begin{tabular}{ccc}
\hline Class & Description & $\begin{array}{c}\text { RFM index } \\
\text { [points] }\end{array}$ \\
\hline I & Roadway stability maintained in an easy way & $86-100$ \\
II & Roadway stability maintained without difficulties & $71-85$ \\
III & Roadway stability maintained with some difficulties & $56-70$ \\
IV & Roadway stability maintained with real difficulties & $41-55$ \\
V & Roadway stability maintained with critical difficulties & $26-40$ \\
VI & No way of maintain the roadway stability & $4-25$ \\
\hline
\end{tabular}

becomes available. The change of mining conditions along the roadway can be met by the roadway division into some sections during the design process. The change in geological conditions comes after working construction completion forces a new support scheme to be designed. For practical application, the permanent support should be designed for the best mining and geological conditions. Every predicted deterioration of the conditions will decrease the RDE index and indicate the necessity of support reinforcement. Given it that the $R D E$ value ranges from 60 to 300, the range of change is therefore 240 . One can therefore assume that the load capacity of support system should increase by $0.10 \mathrm{MN}$ for every 20 point reduction in RDE (Fig. 1). It enables unequivocal prediction of required support reinforcement in relation to RDE index value. The proposed load capacity increment meets current construction and technical limits in this field (Niedbalski, 2014).

The methodology can be used for a both newly designed workings, for which the current mining and geological conditions are set, and for those where changes of conditions were predicted. In the case of altered technical factors (Table 5), the load capacity of support system should be changed based on the RFM index (Fig. 2). The difference between the support size and roadway cross-section size and the workmanship accuracy can greatly affect the RFM index. As a consequence, since support system overloading and working convergence can occur, an increase of support construction load bearing capacity by $0.4 \mathrm{MN} / \mathrm{m}$ per every $25 \mathrm{RFM}$ index points is proposed.

Engineers should react quickly to geological or mining conditions changes which can lead to a deterioration of roadway functionality or loss of roadway stability.

Simple monitoring methods should be used to control the state of the support and rock mass around the roadway, including convergence measurements, roof rocks displacement or separation measurements, or yielding support clamps displacement.

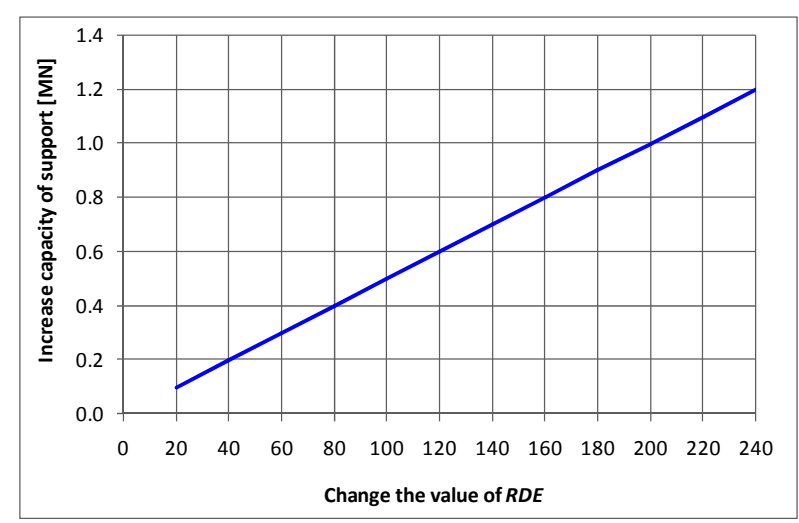

Fig. 1 The support system load capacity increment in the relation to the Roadway Design Efficiency index change.

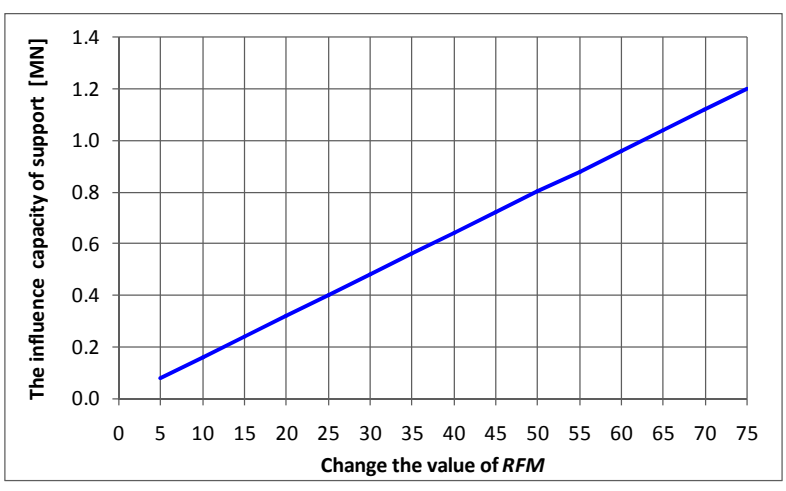

Fig. 2 The support system load capacity increment in the relation to Roadway Functionality Maintenance index change.

\section{CASE STUDIES: RDE AND RFM APPLICATION}

RDE and RFM indices were tested for hard coal mine workings to verify their usefulness. The research has been done in workings where the measurements of damage zone in the roof together with the loads on support frames were being carried out with the help of a borehole endoscope. Endoscopic investigation is the 
Table 9 Roadway Design Efficiency index and Roadway Functionality Maintenance index for selected hard coal mine workings.

\begin{tabular}{|c|c|c|c|c|c|c|c|c|c|}
\hline \multirow[t]{2}{*}{$\begin{array}{l}\text { Workings } \\
\text { name }\end{array}$} & \multirow[t]{2}{*}{$\begin{array}{l}\text { Borehole } \\
\text { position } \\
{[\mathrm{m}]}\end{array}$} & $\begin{array}{c}\text { Geologi- } \\
\text { cal } \\
\text { factors }\end{array}$ & $\begin{array}{l}\text { Geome- } \\
\text { chanical } \\
\text { factors }\end{array}$ & $\begin{array}{l}\text { Mining } \\
\text { factors }\end{array}$ & \multirow[t]{2}{*}{$\begin{array}{l}\mathrm{RDE} \\
\text { index }\end{array}$} & \multirow[t]{2}{*}{$\begin{array}{l}\text { RDE } \\
\text { class }\end{array}$} & $\begin{array}{l}\text { Techni- } \\
\text { cal } \\
\text { factors }\end{array}$ & \multirow[t]{2}{*}{$\begin{array}{l}\text { RFM } \\
\text { index }\end{array}$} & \multirow[t]{2}{*}{$\begin{array}{l}\text { RFM } \\
\text { class }\end{array}$} \\
\hline & & \multicolumn{3}{|c|}{ Points } & & & Points & & \\
\hline $\begin{array}{l}\text { Western } \\
\text { incline }\end{array}$ & 35 & 92.2 & 68.0 & 100.0 & 260.2 & II & 62.7 & 54.4 & IV \\
\hline $\begin{array}{l}\text { Western } \\
\text { incline }\end{array}$ & 215 & 92.6 & 76.5 & 94.4 & 263.5 & $\mathbf{I}$ & 62.7 & 55.1 & III \\
\hline $\begin{array}{l}\text { Western } \\
\text { incline }\end{array}$ & 326 & 92.6 & 78.0 & 94.4 & 265.0 & $\mathbf{I}$ & 62.7 & 55.4 & III \\
\hline $\begin{array}{l}\text { Belt incline } \\
\quad \text { C-3 }\end{array}$ & 110 & 95.2 & 46.3 & 100.0 & 241.5 & II & 56.4 & 45.4 & IV \\
\hline $\begin{array}{l}\text { Belt incline } \\
\quad \text { C-3 }\end{array}$ & 163 & 97.8 & 65.1 & 100.0 & 262.9 & $\mathbf{I}$ & 56.4 & 49.4 & IV \\
\hline $\begin{array}{l}\text { Belt incline } \\
\text { C-3 }\end{array}$ & 260 & 90.0 & 63.5 & 100.0 & 253.6 & II & 56.4 & 47.7 & IV \\
\hline $\begin{array}{l}\text { Connection } \\
\text { roadway Z-3 }\end{array}$ & 67 & 76.4 & 76.9 & 83.8 & 237.0 & II & 56.5 & 44.7 & IV \\
\hline $\begin{array}{l}\text { Connection } \\
\text { roadway Z-3 }\end{array}$ & 342 & 79.0 & 72.0 & 83.8 & 234.7 & II & 66.0 & 51.6 & IV \\
\hline $\begin{array}{l}\text { Test roadway } \\
\quad \mathrm{Cw}_{\mathrm{W}-1}\end{array}$ & 155 & 85.6 & 49.7 & 67.0 & 202.2 & III & 74.7 & 50.3 & IV \\
\hline $\begin{array}{l}\text { Test roadway } \\
\text { Cw-1 }\end{array}$ & 342 & 83.0 & 44.8 & 67.0 & 194.7 & III & 69.1 & 44.9 & IV \\
\hline $\begin{array}{l}\text { Gateroad 2-Z1. } \\
\text { Z2 }\end{array}$ & 216 & 80.4 & 68.4 & 72.4 & 221.1 & II & 63.3 & 46.7 & IV \\
\hline Gateroad B-7 & 248 & 84.8 & 65.0 & 83.2 & 233.0 & II & 74.4 & 57.8 & III \\
\hline Gateroad B-7 & 959 & 87.8 & 58.1 & 100.0 & 245.9 & II & 80.7 & 66.2 & III \\
\hline Gateroad B-3 & 292 & 92.6 & 68.2 & 60.9 & 221.8 & II & 59.4 & 43.9 & IV \\
\hline Gateroad B-3 & 371 & 89.6 & 64.6 & 60.9 & 215.2 & III & 71.3 & 51.2 & IV \\
\hline $\begin{array}{c}\text { Western } \\
\text { roadway } \\
\text { level } 1050\end{array}$ & 237.9 & 83.3 & 54.7 & 100.0 & 238.0 & II & 69.0 & 54.7 & IV \\
\hline $\begin{array}{l}\text { Vent. roadway } \\
\text { W1 level } 1000\end{array}$ & 953.5 & 94.8 & 50.7 & 100.0 & 245.5 & II & 74.2 & 60.7 & III \\
\hline $\begin{array}{c}\text { Roadway W } \\
\text { level } 838\end{array}$ & 456 & 94.8 & 66.1 & 100.0 & 260.9 & II & 57.4 & 49.9 & IV \\
\hline Shaft II bypass & 108 & 91.2 & 79.1 & 100.0 & 270.3 & $\mathbf{I}$ & 64.6 & 58.2 & III \\
\hline Cutter IV & 110 & 54.5 & 41.2 & 100.0 & 195.7 & III & 77.5 & 50.6 & IV \\
\hline \multicolumn{2}{|c|}{ Minimum } & 54.5 & 41.2 & 60.9 & 194.7 & III & 56.4 & 43.9 & $I V$ \\
\hline \multicolumn{2}{|c|}{ Maximum } & 97.8 & 79.1 & 100.0 & 270.3 & $I$ & 80.7 & 66.2 & III \\
\hline
\end{tabular}

best quantitative control of rocks behaviour around the roadways (Majcherczyk et al., 2005, Prusek \& Bock, 2008, Niedbalski et al., 2013). Loads on support frames or performance characteristics of a friction joint in a yielding support as well as the measurement of forces in the instrumented bolt in a roof, in turn, can be good indicators of a support selection (Singh et al., 2004, Brodny 2010, Niedbalski et al. 2013, Majcherczyk et al., 2014). Two or three working sections were investigated. Values of the evaluated RDE index have been compared with the damage zone parameters: range of damage zone, number of fractures and their separation. Values of RFM index were compared with loads on selected supports. The selected workings included varied mining and geological conditions and varied depth in some hard coal mines in Silesian Coal Basin. The evaluated RDE index and RFM index for these roadways are presented in Table 9. 


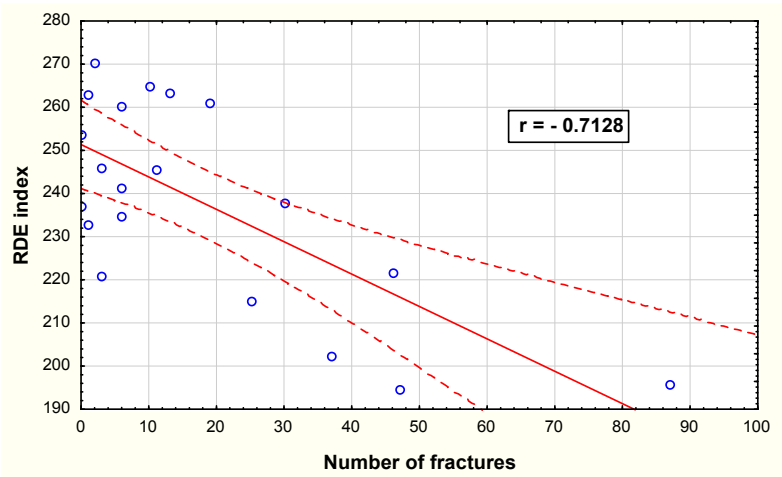

Fig. 3 The relationship between number of fractures and Roadway Design Efficiency index.

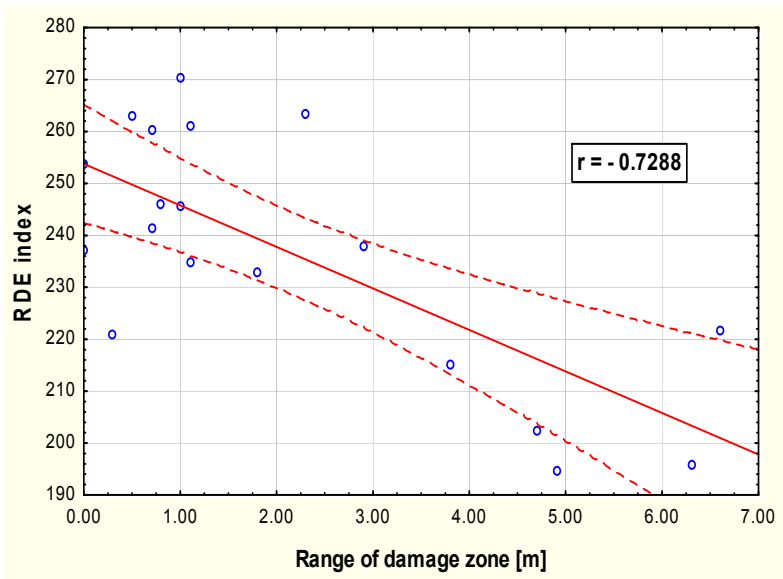

Fig. 5 The relationship between the range of damage zone and Roadway Design Efficiency index.

The total value of the RDE index for the selected workings is between 194.7 (test roadway Cw-1 - $342 \mathrm{~m}$ ) and 270.3 (shaft II bypass - $108 \mathrm{~m}$ ), resulting in an RDE class for the specific workings of I, II, or III, showing that geological and mining conditions are favourable for design (class I), or can be slightly unfavourable (class III). Generally, the conditions around the design workings were similar and their drivage was planned in favourable or average mining and geological conditions. The assessment of geological, geomechanical, and mining factors, based on the point scale, shows that the highest values were given to mining factors, up to 100 points in some cases. This was due to roadways being located in a new mining field with no geological disturbance or previous mining activity. Any change caused by the new mining operations will decrease both this and the $\mathrm{RDE}$ index. In this case, based on Figure 1, the engineers should consider a change in support construction.

The RFM index shows that roadway stability can be maintained with some or even real difficulties (class III or IV). It shows that nearly all of the

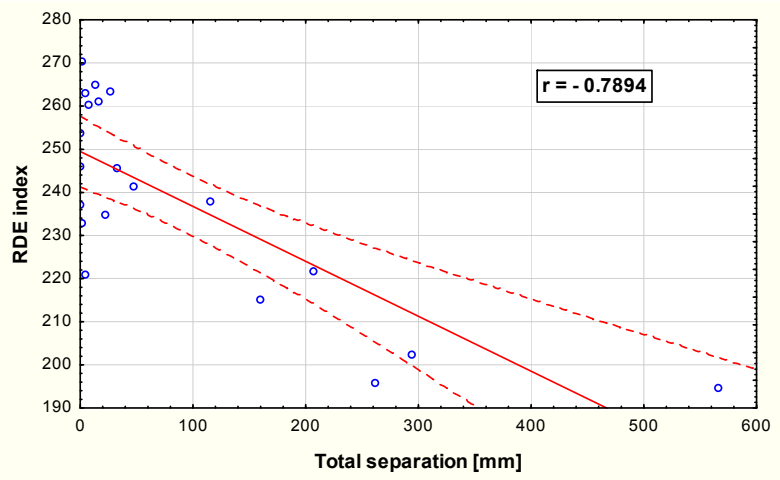

Fig. 4 The relationship between the total roof rocks separation and Roadway Design Efficiency index.

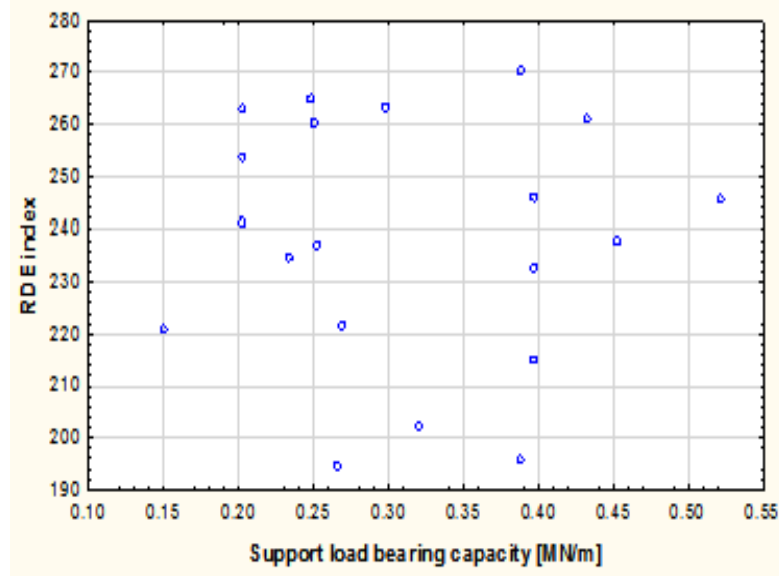

Fig. 6 The relationship between the support load bearing capacity and Roadway Design Efficiency index.

development workings in Silesian Coal Mines are driven in rather fair geological and mining conditions.

The RDE and RFM indices for selected workings were compared with the damage zone parameters in the roof controlled by endoscopic measurements. The range of fracture zones in the roof, change of fracture numbers, and their separation are the most common signs of working instability. Investigations in the field have been carried out for a minimum of one year, which allowed the most intensive rock mass movements to stabilize and a state close to secondary equilibrium. The results have been processed with the help of Statistica software with the $95 \%$ confidence level (StatSoft, 2011).

Analysis of the relationship between the RDE index and the in situ measurements was carried out at over 20 sections of selected roadways, resulting in correlation coefficients $r$ of 0.71 to 0.79 . (Figs. 3, 4 and 5). These values are quite high, giving the coefficient of determination $r^{2}$ of 0.50 to 0.63 , which is satisfactory. The RDE index value drops with number of fracture in the roof (Fig. 3), roof rocks separation (Fig. 4), as well as with higher damage 


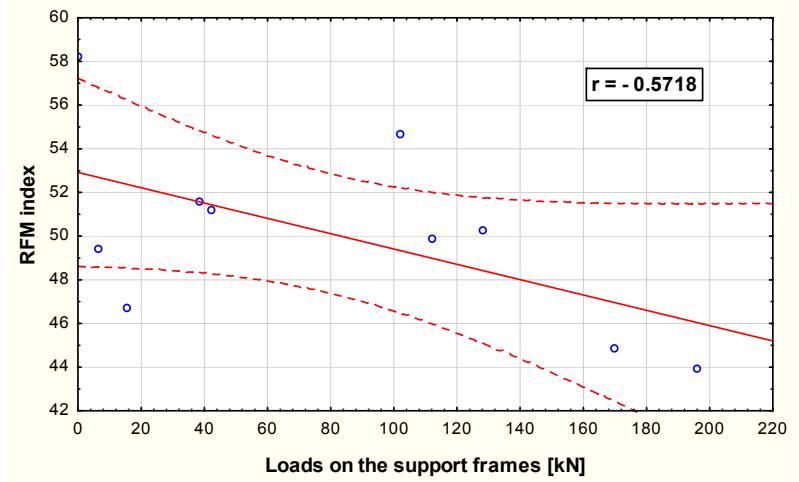

Fig. 7 The relationship between the loads on the support frames and Roadway Functionality Maintenance index.

zone above the roadway (Fig. 5). The figures confirm that RDE index can predict the rock mass behaviour around the monitored workings.

It should be emphasised that the load bearing capacity of the designed support does not suit the RDE index (Fig. 6). There is no correlation (no fit has been done to this point cloud), which suggests that the support selection is not properly adjusted to its predicted performance characteristics. As a consequence, there are weak relationships between RFM index and the loads on the support. In the case of support frames measured with the help of hydraulic dynamometers, there is a relatively weak linear correlation $(\mathrm{r}=0.51)$, but which shows a visible tendency of the load increase on the support frames together with the RFM index reduction (Fig. 7). There is no correlation between the loads on the bolts and RFM index (Fig. 8); however, it should be emphasised that there was a combined steel arch support construction with bolting in the majority of analysed roadways, which probably prevents the roof strata moving down naturally.

There are exceptionally random distribution of measured values, where some factors dominate the others, which lead to other distribution then a normal one. It consider mostly endoscopic research parameters which depends on different factors as, for example: a roof bedding (some roof strata were bedded intensively), a type of support (roofbolting prevents the roof strata from a separation), the way of driving (the rock mass is more damaged by blasting) or mining situation (the exploitation edges, pillars, goafs, the distance to previously mined seams). Some of investigated data suit Shapiro-Wilk test distribution, which is more appropriate for small sample sizes.

It is worth noting that while some results are beyond the assumed confidence level due to a lack of statistical measurements, it should be borne in mind that such investigations are still in progress.

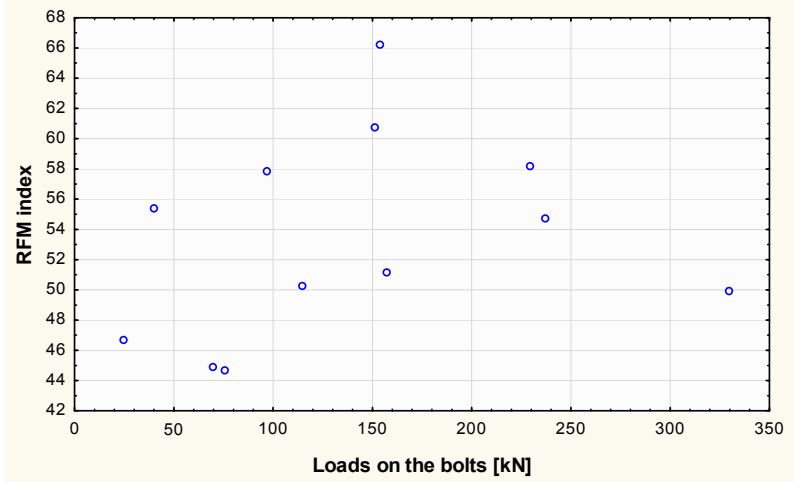

Fig. 8 The relationship between the forces in instrumented bolts and Roadway Functionality Maintenance index.

\section{SUMMARY}

On the basis of the geological, mining and technical factors which influence roadway stability, two indices were developed: Roadway Design Efficiency index, RDE, and Roadway Functionality Maintenance index, RFM. Both should be used at a working design stage. Based on geological, geomechanical and mining, RDE shows the potential difficulties in maintaining roadway stability and in the support design process. RFM takes into consideration the technical factors and assesses the roadway maintenance for a specific time range.

The RDE and RFM indice values were verified from underground measurements taken from selected roadways in the Silesian Coal Basin. Analysing the relationships between the RDE index and rock mass damage parameters around the workings, gives a competent correlation, given the coefficient of determination $r^{2}$ of 0.50 to 0.63 . The correlation between RFM index and support performance controlled by the load on the support frames $\left(r^{2}=0.26\right)$ is poorer; however, in situ research confirms that both indices can be good indicators of roadways stability at a design stage.

The proposed methods of roadways and their support design and roadways functionality control seem to bring practical and economic advantages. The practical advantage of this solution is that it is possible to design the one basic support scheme for the most favourable conditions and reinforcement methods matched to this support. It helps shorten the decision process both when the support construction is overloaded, either due to a predicted fault or mining exploitation or induced by unexpected geological disturbances, or when the load capacity of the support decreases due to rock strength increase, or the lack of expected tectonic disturbance.

Further analyses and mining investigations for geological, mining and technical factors calibration should be continued as only research carried out in different mining regions can verify the indices and the weight of their factors quantitatively. These should 
include not only rock mass behaviour, such as observing beds separation in a roof, loads on the support or the damage zone range evaluation around the working, but other results of ground control measurement, such as a convergence.

\section{REFERENCES}

Brodny, J.: 2010, Determining the working characteristic of a friction joint in a yielding support. Archives of Mining Sciences, 55, No 4, 733-746.

Canbulat, I.: 2010, Roadway roof support design in critical areas at Anglo American Metallurgical Coal's underground operations. Underground Coal Operators' Conference, University of Wollongong \& the Australasian Institute of Mining and Metallurgy, $50-72$.

Feng, X.T. and Hudson, J.A.: 2011, Rock engineering design. London: CRC Press, Taylor \& Francis.

Guptaa, S. and Kumarb, U.: 2012, An analytical hierarchy process (AHP)-guided decision model for underground mining method selection. International Journal of Mining, Reclamation and Environment, 26, Issue 4, 324-336.

DOI: $10.1080 / 17480930.2011 .622480$

Jamshidi, M., Ataei, M., Sereshki, F. and Jalali Seyed, M.E.: 2009, The application of AHP approach to selection of optimum underground mining method. Case study: Jajarm Bauxite Mine (Iran). Archives of Mining Science, 54, No. 1, 103-117.

Kidybiński, A.: 2004, Geotechnical aspects of adaptation of the terminated coal mine workings for underground gas storage caverns. Quarterly Mining and Environment, No. 2, Central Mining Institute, 37-63, (in Polish).

Majcherczyk, T., Małkowski, P. and Niedbalski, Z.: 2005, Describing quality of rocks around underground headings: Endoscopic observations of fractures. Proceedings of Eurock 2005: Impact of human activity on the geological environment, Brno 18-20.05, 355360 .

Majcherczyk, T., Małkowski, P., Niedbalski, Z. and Bednarek Ł.: 2014, Analysis of yielding steel arch support with rock bolts in mine roadways stability aspect. Archives of Mining Sciences, 59, 3, 641-654. DOI: 10.2478/amsc-2014-0045

Małkowski, P., Majcherczyk, T. and Niedbalski, Z.: 2012, Multi-criterion analysis of factors affecting maintenance of roadways. AGH Journal of Mining and Geoengineering, 36, No. 1, 243-252.

Mishra, R.K. and Rinne M.: 2014, Guidelines to design the scope of a geotechnical risk assessment for underground mines. Journal of Mining Science, 50, No. 4, 745-756, DOI: 10.1134/S1062739114040152
Niedbalski, Z.: 2014, Functionality maintenance of headings in hard coal mines: a proposal for prognosis methodology. Wydawnictwa AGH, Kraków, (in Polish).

Niedbalski, Z., Małkowski, P. and Majcherczyk, T.: 2013, Monitoring of stand-and-roof-bolting support: design optimization. Acta Geodyn. Geomater., 10, 2, 215 226. DOI: 10.13168/AGG.2013.0022

Namin, F.S., Shahriar, K., Bascetin, A. and Ghodsypour, S.H.: 2009, Practical applications from decisionmaking techniques for selection of suitable mining method in Iran. Mineral Resources Management, 25, 3, 57-77.

Protosenya, A.G. and Trushko, V.L.: 2013, Forecast of excavation stability in weak Iron ore in terms of the Yakovlevsky Deposit. Journal of Mining Science, 49, No. 4, 557-566.

Prusek, S. and Bock, S.: 2008, Assessment of rock mass stresses and deformations around mine workings based on three-dimensional numerical modelling. Archives of Mining Sciences, 53, 3, 349-360.

Saaty, T.L.: 1980, The Analytic Hierarchy Process. McGraw Hill, New York.

Singh, R., Singh, A.K., Mandal, P.K., Singh, M.K. and Sinha, A.: 2004, Instrumentation and monitoring of strata movement during underground mining of coal. Minetech, 25, No. 5, 12-26.

StatSoft, Inc.: 2011, STATISTICA, version 10. www.statsoft.com.

Wang, T. and Fan, Q.: 2000, Optimization of soft rock engineering with particular reference to coal mining. International Journal of Rock Mechanics and Mining Sciences, 37, 535-542.

DOI: 10.1016/S1365-1609(99)00080-5 